\title{
THE ROTHAMSTED FIELD EXPERIMENTS ON THE GROWTH OF WHEAT
}

\author{
By Dr. R. D. Preston \\ UNIVERSITY OF LEEDS
}

$\mathrm{I}^{\mathrm{T}}$ is perhaps fortunate that the approaching centenary of the Broadbalk experiment at Rothamsted has stimulated the publication of a detailed report on wheat studies carried out there, at a time when interest is growing rapidly in the question of the relative merits of farmyard and artificial manures. The Broadbalk experiment in particular has continued over a period sufficiently long to detect any progressive deterioration in the crop, resulting from the continuous use of artificial fertilizers. The present report ${ }^{x}$ is of particular interest, since it includes not only the continuous wheat experiments themselves, but also a comparison with a variety of rotation experiments and with ordinary farming methods at a variety of stations.

The Broadbalk wheatfield was last year harvested for the ninety-seventh time in succession, and this is the third discussion which has appeared during that time. On the first occasion (1893) the first fifty years were reviewed by Lawes, the founder of Rothamsted, and his collaborator Gilbert, and on the second by A. D. Hall in 1905. Since 1919, the scope of the experiment has been widened considerably, and in particular the application of statistical methods not previously available has enabled much more information to be extracted from the existing data.

The Broadbalk field slopes downward from east to west, and is divided into strips running down the slope, each of which annually receives the same manurial treatment, different from that in other strips. There is no obvious important trend in fertility across the field; the soil is, in fact, everywhere rather poorly adapted to wheat cultivation, as evidenced by the relatively low yield (maximum 55 bushels per acre as against 60 bushels often yielded on farms and one observed yield of 96 bushels). Originally set up to disprove Liebig's theory that plants receive all their nitrogen from the air, many valuable data have been accumulated on the relative effectiveness of farmyard manure and a range of artificial fertilizers. It was early demonstrated that addition of nitrogen to the soil markedly increases the yield of grain and straw (for example, $44 \mathrm{lb}$. of nitrogen as ammonium sulphate gives an increase of 1 bushel of grain) but that minerals are also necessary. For grain production, sodium nitrate is considerably more effective than ammonium sulphate in a single dressing (43 lb. per acre) but not so much with a double dressing. For straw production sodium nitrate is always decidedly the more effective, and for both straw and grain spring application is preferable to autumn (due probably to less leaching from the soil). Levels of supply well above those in ordinary practice give greater yields. Perhaps the most important point in this connexion is that farmyard manure has only 44 per cent of the efficiency of sodium nitrate, and only 50 per cent of that of ammonium sulphate, when the artificial manures are added with complete minerals. Potassic fertilizers increase the yield both of straw and grain, an effect which is diminished by phosphate deficiency. This higher efficiency of artificial fertilizers does not appear to be offset by eny progressive deterioration in the crop. During the period 1852-1918 the annual diminution in yield (eliminating random variations) was certainly lowest with farmyard manure $(0 \cdot 1$ per cent of mean yield), but this was closely followed by the plot with complete artificials $(0 \cdot 26$ per cent). The highest rate of deterioration was found in the plot receiving nitrogen and $\mathrm{PO}_{4}$ without potassium, where it amounts to 1 per cent. It is interesting that on the unmanured plot, though yields fell from 20 bushels per acre to 10 in twenty years, they have not fallen lower except when weeds have become prevalent; in fact, during recent years they have risen.

This annual deterioration is attributed largely to changes in soil composition. All the plots with the exception of the farmyard manured have lost carbon and nitrogen compounds, but though the soil in the farmyard manured plots is different from that in others as regards physical properties there is no evidence that this soil is better suited to the wheat plant. There is certainly no suggestion, as the years go by, of progressive injury by rusts or by insect pests, though 'eye spot lodging' is somewhat more common than on crops grown in rotation.

Apart from this slight steady deterioration, the so-called 'annual variations' related to weather conditions, chance variations in cultivation, etc., have also been studied in detail. The main causes of such variations in yield are almost solely connected with weather factors; contrary to general belief time of sowing has no observable effect. The defect of the Rothamsted climate for wheat is that rainfall is much too high. In general it may be said that injury due to rain is least in October and greatest in or about January, when each additional inch of rain reduces the crop by one or two bushels per acre. This effect of winter rainfall is to be attributed partly to a leaching out of nitrogen (and is therefore least marked with farmyard manure), partly to excessive growth of weeds and, at Broadbalk, partly to the already heavy nature of the soil. The rainfall effect accounts for about $\frac{1}{4}-\frac{1}{3}$ of the total annual variation on most of the plots, though on the farmyard manured plots the effect covers about 40 per cent of the total and is the most important single factor concerned.

The chief practical difficulty in continuous wheat cultivation is the fight against weeds. The time between harvesting one crop and sowing the next is short and is usually not suited to the effective killing of weeds, and control is complicated by delayed germination of some weed seeds (2-9 years or more). The relation between weed infestation and wheat yield is not simple, but it is proved that wheat is ill fitted to stand up to the competition of weeds. Introduction of a fallow in order to eradicate weeds proved a success. The yield, which had been deteriorating, jumped immediately to the original level; an effect which is perhaps all the more striking as it lasted only one year. The main points about fallowing appear to be (1) that it enables control of weeds to be made and allows the formation of a better seed bed and soil conditions; (2) it allows an 
accumulation of nitrogen which may be very considerable (rising in plots with minerals only to the level of one with minerals plus $86 \mathrm{lb}$. $\mathrm{N}$ as ammonium sulphate); (3) it emphasizes the need for potash. Although the effect of a single fallow is so marked, a continuous wheat-fallow rotation commenced in 1856 (Hoos field) showed that the effect does not continue and a prolongation of the fallow to three years (Hoos field, 1932) or four years (Broadbalk, 1930) does not materially increase the yield. As regards the success of the old three-field system, it must be remembered that medieval fallows were never clean fallows; the land was left to natural vegetation and was grazed.

In 1930 an experiment on modern lines was begun at Rothamsted and at Woburn involving a sixcourse rotation of both crops and treatment. The wheat follows clover, and the yields without added manure are so good that added nitrogenous fertilizers have no effect at either station. Additional potash slightly increases the yield (Rothamsted) or, like phosphates, has no effect. In normal rotation conditions at Rothamsted (the Norfolk rotationswedes (manured), barley, elover, wheat) begun in 1848 the addition of manure to the swedes had no effect on the wheat for the first twenty years, though afterwards the yields on unmanured land deteriorated more than on the manured. When clover failed it was replaced by beans, and both crops were found better than fallow except on unmanured land. The yields on all plots were similar, and resembled the Broadbalk continuous wheat yields with farmyard manures. In a mangold, barley, beans, wheat rotation (Saxmundham, commenced in 1899), however, the increase in yield with nitrogenous manure is almost the same as on Broadbalk, and here again the effectiveness of farmyard manure is considerably less (30 per cent) than that of sodium nitrate.

An analysis of the development and composition of the wheat plant as affected by fertilizers has produced results of no less interest. Up to a certain point increased nitrogen has no effect on the composition of the wheat plant or on its habit of growth, and this point can be carried to a higher level of nitrogen supply by giving potash and phosphates. Finally, however, a point is reached at which nitrogen is in excess; the leaves become liable to fungus attack, the crop tends to lodge, and the straw remains green for a longer time and dries slowly at harvest. The variation of composition with season is much more marked than with manuring. Milling and baking tests show no significant effect of treatment on quality, and the recent claim that wheat grown with farmyard manure is of better nutritive quality than wheat grown with artificial fertilizers is not supported by the Broadbalk samples as regards vitamin B. ${ }^{1}$

Continuous wheat cultivation has not found favour in England for a variety of reasons. Nevertheless, where a good outlet can be found for the straw, very frequent wheat growing has proved profitable provided the manurial system be sound; it has, in fact, been followed by a number of farmers with success. It is at least quite clear that, should continuous wheat growing be taken up in England, these experiments at Rothamsted will prove of inestimable value. On one point they are especially conclusive. No amount of manuring and no elaborate care in cultivation will ever raise a second-class wheat field into the first class.

${ }^{1}$ Sir E. J. Russell and D. J. Watson, Imperial Bureau of Soil Science Technical Communication No. 40, 1940. 7s. $6 d$.

\section{FORTHCOMING EVENTS}

[Meeting marked with an asterisk is open to the public.]

\author{
Monday, May 12
}

Royal Geographical Society (at Kensington Gore, London, S.W. 7), at 5 p.m.-Sir Charles Arden-Close, F.R.S., Mr. F. S. Richards, Mr. Arthur R. Hinks, F.R.S.: "Map Projections and Sun Compasses".

\section{Tuesday, May 13}

Royal Socrety of ARTs (at the Institution of Electrical Engineers, Victoria Embankment, London, W.C.2), at 2.30 p.m.-Lieut.-General A. G. L. McNaughton : "Research in Canada".

Royax Instrtution of Great Britain (at 21 Albemarle Street, London, W.1), at 5.15 p.m.-Dr. Alexander O. Curle: "Glimpses of 2,000 Years of Home Life: as Revealed by Excavations in the North of Scotland".*

Institute of Physics (London and Home Counties' Branch) (in the Lecture Hall of Messrs. Kodak, Ltd., Harrow), at 6 p.m.-Dr. C. Sykes: "Thermal Effects in Transformations in Metals".

\section{APPOINTMENTS VACANT}

APPLICATIONS are invited for the following appointments on or before the dates mentioned:

Lecturer in Meohanical Enginefring at the Leeds College of Technology-The Director of Education, Education Department, Calverley Street, Leeds 1 (May 19).

DEPUTY BOROUGH ELECTRICAL ENGINEER in the Electricity Undertaking of the Woolwich Metropolitan Borough Council-The Borough Electrical Engineer, Electric House, Powis Street, Woolwich, London, S.E.18 (May 19)

LECTURER (GRADE 2B) IN ELECTRICAL ENGINERRING-The Registrar, University, Leeds (May 19).

MANAGER OF THE Wrodght LIGHT ALloYs Developmant AssocIATION-Mr. Eric L. Heathcote, Wrought Light Alloys Development Association, 25 Bennetts Hill, Birmingham 2 (June 7).

Professor of MATHeMatics-The Bursar and Deputy Registrar, University College of North Wales, Bangor (June 30).

GRADUATE TEACHER IN ENGINERRING at Kenrick Technical College - The Director of Education, Education Offices, Highflelds, West Bromwich.

Assistant Enginegr for the SUdan RaILways-The Controller, Sudan Government London Office, Oxford Hotel, 261 Clifton Drive South, Lytham St. Annes, Lancs. (quoting 'Assistant Engineer').

Assistant Engrneer in the Government of Zanzibar Public Works and Electricity Department-The Crown Agents for the Colonies, 4 Millbank, London, S.W.1 (quoting M/9634).

Teacher of Engrnekring SubJects-The Principal, Technica School. Cole Street, Scunthorpe, Lincs.

\section{REPORTS AND OTHER PUBLICATIONS}

(not included in the monthly Books Supplement)

\section{Great Britain and Ireland}

National Central Library. 24th Annual Report of the Executive Committée, 1939-1940. Pp. 16. (London: National Central Committee, 1939-1940. Pp. 16. (London: National Central
[244 Proceedings of the Royal Society of Edinburgh. Section B (Biology) Vol. 61, Part 1, No. 4: The Hydroid of the Medusa Cosmetira pilosella Forbes. By W. J. Rees. Pp. 55-58. (Edinburgh and London : Ollver and Boyd.) $6 d$.

\section{Other Countries}

Field Experiments on Sugar Cane in Trinidad-Annual Report for 1940. By P. E. Turner. Pp. 260. (Trinidad: Government Printer, Port-of-Spain.)

Department of Science and Agriculture, Jamaica. Bulletin No 25: Reprints of Miscellaneous Articles, 1938. Pp. 1ii +92 . 6d Bulletin No. 26: Banana Leaf Spot Investigations, 1: The Basis of Control. By R. Leach. Pp. ii +8. 6d. (Kingston: Government Printer.)

Proceedings of the United States National Museum. Vol. 89, No. 3098: Coch 3098: Echinoderms from Greenland collected by Capt. Robert A. Bartlett. By Austin H. Clark. Pp. 425-434 + plate 58. Vol. 89, No. 3103: Dinotocrinus, a New Fossil Inadunate Crinoid Genus. By Kdwin Kirk. Pp. 513-518+plate 63. Vol. 89, No. 3014: A Supposed Jellyfish from the Pre-Cambrian of the Grand Canyon. By R. S. Bassler. Pp. 519-522 + plate 64. (Washington, D.C. : Government Printing
Office.) 